\title{
Rethinking the Library Space
}

\section{Interdepartmental Collaboration for Student-Centered Services}

By Wesley Custer, Asbury Theological Seminary

ABSTRACT The Florida Dunnam Campus of Asbury Theological Seminary underwent some major changes in the area of library services over the past few years. This presentation contains the ways in which these changes were influenced and accomplished through interdepartmental cooperation and collaboration. The redesign of the library space became a means by which we could provide a better academic community in a designated space with staff, resources, and comfortable seating.

\section{INTRODUCTION}

In 2013, I became the manager of the library for the Florida Dunnam Campus of Asbury Theological Seminary in Orlando, Florida. I had been working there since 2006 in various capacities, and now I had some influence over how the physical space was arranged and how the departments collaborated on campus. I began to talk to people, saying that I wanted the library to be able to be open whenever the campus was open. What prevented this was simply our budget. I could not pay for workers to keep the library open. The best answer that I could think of was partnering with other departments to keep the library open. Now the library is a room in the middle of the first floor of the building in Orlando, and that made it possible to make the library central to the campus.

\section{PHASE ONE}

I spoke with our facilities foreman and talked to him about the possibility of cross-training the security personnel to check books in and 
out. The goal was not truly library services, but rather to simply keep the doors open and the lights on. This was to provide the students with a place and keep the books, printing, and scanning available. These efforts largely failed because the location of the evening security team was too far removed from the library services area. During this time, I and my team rotated evening hours to ensure full library services.

\section{PHASE TWO}

I started casting a vision for the library space: a place for commuting students and their families to work, study, and relax whenever the building was open. When the facility was originally built, it was a classic library. Books occupied most of the space in the library with a few desks and a couple of study rooms. Times have changed, and it was obvious by the end of 2015 that the library needed a facelift. A large part of this change was motivated by the changing face of our student body. They are all commuting students on the Florida Dunnam Campus, and as such, they need good spaces to rest, study, and simply be while they are on campus.

We managed to make some significant but relatively minor changes to the arrangement of the space over the next two years. We would make a change, gather information, and iterate based on feedback. All the while, we kept looking for and asking for funds to do a bigger facelift. Conversations with enrollment management and the vice president of the campus were beginning to be fruitful.

\section{PHASE THREE}

Finally, in the spring of 2017, a conversation and vision meeting with the VP of enrollment management and operations for the Florida Dunnam Campus had a breakthrough. I was finally able to cast the vision in such a way that he saw the potential for student retention and EMT events in the library space. This opened up some funding, and when I gave him a budget for replacing flooring, replacing the services desk, and purchasing new technology/furniture, he managed to get buy-in from others and got us the funding.

That meant that we needed to shift the whole collection in order to open the floor space that we wanted. We managed to open up a 30 'x60' space in the library that allows for collaborative work, coffee/ 
snack space, community events, staff meetings, EMT events, and study space. We replaced the flooring from dingy carpet to new LVP (luxury vinyl plank) flooring, painted the whole library, and demolished an oversized circulation desk, replacing it with smaller, very efficient services desk.

Functionally, they have moved the reception area into the library space and removed the doors. Now, the library is available whenever the campus is open. Students are able to access library physical resources whenever they are on campus, and there is always a person available to help them. These changes were quite opportune in that there were major budget cuts coming, and ultimately the basic library services had to be delegated to EMT staff because we had to reduce all the staff from the library on that campus.

The challenges we face now are completely expected. We need to work hard to keep library services moving for those not on the main campus in Wilmore, Kentucky. Meeting and communicating with the EMT team on the Florida Dunnam Campus to keep things going and giving them information as we make small changes will be key. 